\title{
THE ORIGINS AND EFFECTS OF PARTY FRAGMENTATION IN VANUATU'
}

\section{Michael G. Morgan}

\section{Introduction}

This chapter details the origins of Vanuatu's political parties, their policy platforms, parliamentary representation and core constituents, including the particular linguistic, regional and religious biases of each party. In so doing, it charts the progressive fragmentation of Vanuatu's political parties since the late 1980s. At independence in 1980, party politics were polarised largely between the monolithic anglophone Vanua'aku Pati (VP) and an alliance of predominantly francophone opposition groups, the Union of Moderate Parties (UMP). For almost a decade, the VP dominated the Parliament, commanding a nearly two-thirds majority. After 1988, the VP splintered into progressively smaller factions. The subsequent fragmentation of the UMP has created a Parliament of shifting alliances and unstable coalitions. Encouraged by the peculiar political culture of Vanuatu - in which the electoral system and the society in which it operates present few disincentives for factionalisation - this has led to endemic political instability, which has weakened the law-making and oversight functions of Vanuatu's Parliament and made marshalling the numbers to form government the principal task of parliamentary parties. Across the spectrum of Vanuatu's political parties, policy variations have narrowed as the pragmatic considerations of establishing allegiances have brought about the erosion of the distinct party platforms developed during the 1970s. National politicians in Vanuatu now often appear motivated primarily by staying in power. ${ }^{2}$

This has created new challenges for Vanuatu's MPs. Endemic political instability precipitated the Comprehensive Reform Programme (CRP) and countering the consequences of political instability has been the intention of several programs undertaken 
under the auspices of the CRP. The growing number of foreign advisers undertaking core tasks of the CRP has reignited the issue of Vanuatu's sovereignty and, consequently, support - or otherwise — for the reform agenda has become a major point of differentiation between Vanuatu's political parties.

Drawing these issues together, this chapter examines the coherence of contemporary political groupings, the fragility of government coalitions, the impetuses for party fragmentation, and makes comment on the long-term viability of Vanuatu's current set of parliamentary parties. It includes a review of parliamentary numbers since 1980 and it will provide a prognosis of the single non-transferable vote (SNTV) electoral system in which they operate.

\section{Background}

Geographically, the Republic of Vanuatu comprises an archipelago of about 80 islands and reefs, some 70 of which are inhabited. At the time of the 1999 census, its population was 186,678, with almost 80 per cent of that number residing in the rural areas of Torba, Sanma, Penama, Malampa, Shefa and Tafea Provinces. ${ }^{3}$ The urban population, however, is expanding rapidly ( 4 per cent per annum), with more than twenty per cent of the population now residing in Port Vila and Luganville.

Previously known as the New Hebrides, the republic, until 1980, was administered jointly by France and Britain under the Anglo-French Condominium created in 1914, bequeathing Vanuatu bifurcated educational, legal and administrative systems. ${ }^{4}$ At independence, Vanuatu declared French, English and Bislama to be the official languages. Given the strong colonial rivalries between the UK and France, the divisions cleaved by colonialism were thought to have been replicated in the Melanesian societies in the New Hebrides, ${ }^{5}$ and to have inflected the emergent political culture of the archipelago, rendering political groups - somewhat unproblematically — as anglophone or francophone. ${ }^{6}$ Such dichotomies simplify Vanuatu's political landscape and sometimes serve colonialist agendas, which subordinate local motivations in favour of colonial or narrow nationalist purviews. ${ }^{7}$

The point is not to discredit the influence of the colonial powers on political mobilisation entirely, but to recognise the porous and shifting nature of political allegiances in Vanuatu, to problematise 'anglophone' and 'francophone' as absolute political polarities. Most of Vanuatu's political parties share one of two common points of origin, emerging either from the VP or the UMP, although former members of these parties might now be unified in membership of one of Vanuatu's newer parties. Given that the VP came to support a one-language, anglophone education policy in the late 1970s and that much of its elite emerged from Protestant, anglophone education, it has been characterised accurately as an anglophone party. Included in the diverse camp of 'francophone' parties, however, have been several arguably anglophone political groups, opposed ideologically to the centralist, clergy-led nationalists of the VP. Natatok Efate, one such group, was the VP's main opponent on Efate in the inaugural national elections in 1979. The party fielded only anglophone candidates, yet derived much of its electoral support from francophone-dominated areas on the outskirts of Vila, particularly Montmartre and 


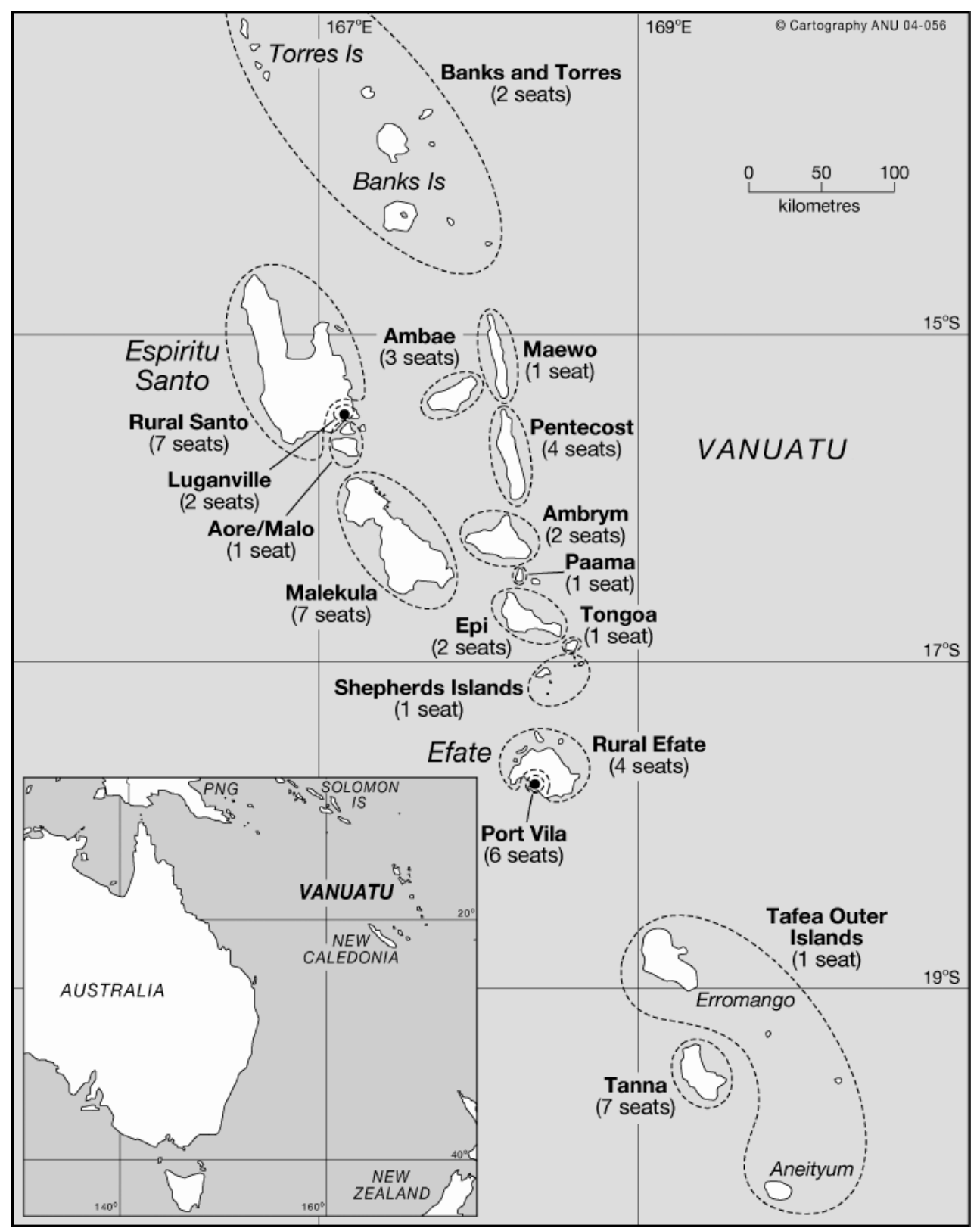

Figure 7.1: Vanuatu: SNTV multi-member constituencies 
Erakor. ${ }^{8}$ Ideologically, Natatok Efate was closer to the Modérés than to the VP. The sweep of French and British influence in Vanuatu should not be underdrawn. Given that the French Administration appeared determined to thwart independence and actively fomented rebellion, most opponents of the nationalist VP have been implicated in the rebellion in one way or another. ${ }^{9}$ The perceived intervention of French colonial officers, in particular, raised the ire of the nationalist VP, souring relationships between France and Vanuatu after independence and unfairly tarring all francophone ni-Vanuatu with the brush of sedition. ${ }^{10}$ The rebellion — and, to a lesser degree, the polarised political landscape - was more than simply a French and francophone plot. Nagriamel, for example, was multi-ethnic, multilingual and multi-denominational in composition, its eventual cooptation to French and other agenda notwithstanding. Today, anglophone, Protestant communities in Ambae, Pentecost and Maewo support the UMP electorally because of shared histories of involvement in the Nagriamel movement. Beneath the veneer of the candidates and sitting members, it is much harder to delineate clearly between anglophone and francophone camps.

What unified the UMP was its opposition to the VP's rigid centralism. Indeed, despite accepting some level of decentralisation into their platform in the late 1970s (largely at the urging of French Minister for Overseas Territories [DOMTOM], Paul Dijoud ${ }^{11}$ ), the VP was opposed to incorporating it fully on the grounds that it would make legitimate the agendas of their federalist and secessionist political opponents. Although the VP platform incorporated some level of decentralisation, in practice its policies were geared towards strengthening the central authority of government and party apparatuses. The UMP, in comparison, favoured greater regional autonomy, a policy born out of its fragmented origins, and one that most of its breakaway factions have inherited. For the first decade after independence, therefore, it would be equally meaningful to delineate Vanuatu's political blocs into federalist and centralist camps, in addition to the basic francophone/anglophone divide, recognising also the slippages between these groupings.

The next section provides an overview of past and present parliamentary parties in Vanuatu. Each entry offers historical data on party origins and the particular regional and linguistic affiliations of each group. Where available, the distinct platforms and party structures of the parties are also depicted.

\section{The Vanua'aku Pati (VP), established in 1977 (1971)}

Vanuatu's first orthodox political party, the Vanua'aku Pati is also its most successful, having governed for nearly 15 of the past 24 years. Originally named the New Hebrides National Party (NHNP), it was formed in Santo in 1971 by members of the Anglican and Presbyterian clergy, junior British Administration bureaucrats and teachers. ${ }^{12}$ In 1977, in line with its nationalist agenda, the NHNP was renamed the Vanua aku Pati (Our Land Party). Father Walter Lini, a Melanesian Mission priest based in Longana, east Ambae, and teachers Peter Taurokoto and Donald Kalpokas, both Presbyterians, constituted the party's core leadership group.

After its formation, the party pressed for the rapid decolonisation of the New Hebrides through a concerted program of demonstrations and political agitation. ${ }^{13}$ 
While NHNP leaders often appeared impatient with the colonial powers, they were broadly supportive of the institutions of state; their major grievances with the Condominium stemmed from disagreements over the timetable for decolonisation. Like nationalist parties elsewhere in the decolonising world, the VP was determined to maintain the territorial integrity of the New Hebrides, post-colony, despite the emergence of federalist movements in the southern and northern islands in the 1970s, fomented largely by foreign agents. ${ }^{14}$ When the VP won the 1979 national elections, fought over the issue of independence and who would lead the New Hebrides afterwards, these groups attempted open secession. With support from PNG, Australia and New Zealand, the Lini Administration suppressed the rebellion. ${ }^{15}$ Because many French colons supported the revolts and because the French Metropolitan Government and Colonial Administration were seen to be complicit in the rebellion's planning, the VP adopted an anti-French stance in the early 1980s, culminating in the expulsion of the French Ambassador. ${ }^{16}$

Integral to the VP's original platform was the return of alienated land, the development of Vanuatu and respect for kastom. Initially, this was conceived under the rubric of 'Melanesian socialism', derived in part from the writings of African nationalists Julius Nyerere (Tanzania) and Kwame Nkrumah (Ghana), but sharing much with the emerging discourse on 'the Melanesian Way' articulated most clearly by Bernard Narakobi. ${ }^{17}$ Its foreign policy was based on its membership of the Non-Aligned Movement (NAM), and involved advocacy for the decolonisation of the remaining Melanesian colonies (West Papua and New Caledonia) and a rejection of Cold War alliances. In practice, this policy allowed it to play off one foreign power against another. In the decade after independence, Australian policy-makers perceived in the growth of relations between Vanuatu, Cuba, Libya and the Soviet Union serious threats to ANZUS policy imperatives in the South-West Pacific, which prompted periodic increases in Australian aid budgets to Vanuatu. ${ }^{18}$ Such concerns subsided with the ending of the Cold War. Ever since, VP has gravitated towards centrism.

Like most of Vanuatu's parties, the VP still places a high emphasis on nationalism, the maintenance of traditional culture, customs and national sovereignty. It is the only party with detailed provisions for the empowerment of women built into its party platform. ${ }^{19}$ In recent years, recognising Vanuatu's dependency on foreign aid and precipitated by endemic political instability, the VP has become the party of institutional reform, supporting the Asian Development Bank-sponsored CRP. In 2002, this became fixed in the party platform: growing the economy and strengthening public administration. ${ }^{20}$ In light of attacks from within the party membership on the CRP as an instrument of foreign domination, VP leaders have proposed a much shorter list of achievable reform priorities and have posited a much greater emphasis on grassroots support. $^{21}$

Parallel with the increasing emphasis on reform was growing disenchantment within the party about its direction and policies. The aspirations of a generation of younger MPs have created splits within the party. Tension culminated in the early months of 2004, when three senior Members of Parliament, including former Prime 
Minister Donald Kalpokas, formed a dissident group, termed the Vanua K Group by the Vanuatu Electoral Commission to differentiate it from the other VP factions (see below). Although their position within the party is yet to be determined by the deliberative bodies of the VP, Vanua $\mathrm{K}$ members consider themselves to be core members of the VP who maintain support from its rank and file. In terms of electoral returns, however, the split allowed the defeat of senior VP candidates in heartland constituencies such as Tanna and Tafea Outer Islands in the 2004 elections.

The VP is governed by the People's Congress, constituted by delegates from regional subcommittees, island delegates (where there are no subcommittees), members of the commissars' council and members of the National Executive Council. Administrative functions are determined by the Central Administrative Council, which includes the major office-bearers of the party (president, treasurer, secretary et al.), women's and young people's delegates, provincial and municipal councillors and other members as determined by the People's Congress.

The separation between the parliamentary, executive and administrative wings of the party has eroded in recent years. The basic party functionaries are the Commissars (Komisa), who are elected by regional subcommittees for two-year terms and who must be residents of the area they represent. Commissars are responsible for long-term party planning.

\section{The Union of Moderate Parties (UMP), established in 1981 (1973)}

The Union of Moderate Parties began its existence at independence as an amalgam of groups opposed to the majority VP. Principal among its constituent groups were the urban Union Communautes des Nouvelles Hebrides (UCNH) and the Mouvement Autonomiste des Nouvelles-Hebrides (MANH), both formed in 1973. The party also attracted support from the Tan Union on Pentecost, Namangki Aute from Malakula, former Nagriamel supporters in Santo, Pentecost, Ambae and Maewo, and from Jon Frum and other social movements in Tanna and the southern islands. Referred to before independence as the Modérés, to distance themselves from the 'young radicals' in the VP, the groups renamed themselves the UMP in 1981, arguably to distance themselves from the stigma attached to the rebellion. ${ }^{22}$ The UMP draws electoral support from across Vanuatu, concentrated in Sanma, Penama, Tafea and Shefa Provinces. Its support is particularly pronounced in the urban constituencies of Port Vila and Luganville.

Central to the UMP's policy platform is the fostering of economic activity in rural areas through the maintenance of copra and kava prices at levels acceptable to farmers. Under the leadership of Maxime Carlot Korman (1991-95), the UMP advocated the private ownership of land, one of two parties to have done so (the other is Korman's current party, VRP). Currently, this policy has subsided in importance. The party is currently led by Serge Vohor, MP for Santo Rural.

The principal deliberative body of the party is the national congress. Throughout the 1990s, however, severe factional splits emerged within the party and the deliberations of the congress became secondary to political brawling between factional leaders. Decisions taken by the congress were subject to intensive judicial scrutiny. 


\section{National United Party (NUP), established in 1991}

Former Prime Minister Father Walter Lini and 21 dissident VP members founded the National United Party in 1991, after Lini's ouster from the presidency of the VP. Its former president was Dinh Van Than, a naturalised Vietnamese citizen whose close alliance with Lini precluded any rapprochement with the nationalist VP (who have long considered Than an exploitative foreigner). The ouster of Than as president in favour of Ham Lini, Walter Lini's brother, allowed for its rapprochement with the VP. The party's strongholds are Penama and Torba in northern Vanuatu, but it has won seats in Tanna, Luganville and Port Vila.

Like the VP, the NUP maintains a nationalist platform, seeking to 'promote, to preserve, to revive and to encourage Vanuatu Culture ... and ... [to encourage] a higher standard of living and status for Ni-Vanuatu'. ${ }^{23}$ In recent years, it has campaigned against the continuation of the CRP.

The NUP's party structure is derived in large part from that of the VP, with party authority emanating from the deliberative People's Congress. Similarly, the Central Administrative Council determines administrative functions.

\section{People's Democratic Party (PDP), established in 1994, ceased 1998}

Four dissident members of the NUP formed the PDP in 1994 after they questioned the influence of Dinh Van Than over party direction. Led by Pastor Sethy Regenvanu, the MPs defied Lini to accept government positions after the NUP was expelled from a UMP-led coalition government. Three out of the four PDP MPs were voted from office in 1998. Onneyn Tahi, the fourth rebel MP, returned to the VP in $1997 .{ }^{24} \mathrm{He}$ died in a car crash on Ambae in the lead-up to the 1998 elections. The PDP no longer exists as a parliamentary party.

\section{Tan Union, established in 1977, ceased 2001}

According to Vincent Boulekone, a founding member of the party, Tan Union was formed in 1977 to provide an umbrella for all those groups opposed to the VP but broadly supportive of independence. ${ }^{25}$ Unlike the VP, Tan Union advocated delayed independence to allow for New Hebrides to develop more. New Hebrides' second Chief Minister, the late Père Gerard Leymang, was a Tan Union member. After the formation of the UMP in 1981, Tan Union formally merged with the new party, with Vincent Boulekone becoming its first president.

Serge Vohor sacked Boulekone from the party in 2000, along with three other senior MPs. The next year, the Tan Union formally merged with the Grin Pati (see below). ${ }^{26}$ Boulekone did not contest the 2002 elections. Tan Union no longer exists as a discreet parliamentary party.

\section{Melanesian Progressive Party (MPP), established in 1988}

The Melanesian Progressive Party was formed in 1988 after Barak Sope was expelled from the VP and the National Parliament because of his role in inciting the Vila Land Riots, sparked when the Government tried to dismantle the trust fund in which money used to purchase Port Vila from its traditional landowners, including Sope's home 
community Ifira, was held. Of all the parties, the MPP most closely follows the original platform of the VP, advocating still for the decolonisation of West Papua and championing an autonomist foreign policy. In opposition, the MPP has campaigned against the CRP as a vehicle of neo-colonialism and its members have openly attacked core projects of the CRP and constitutional offices, such as the Ombudsman. ${ }^{27}$

MPP's structure closely resembles that of the VP.

\section{People's Progressive Party (PPP), established in 2001}

Sato Kilman, the former Deputy President of the Melanesian Progressive Party, formed the People's Progressive Party after a falling out with Barak Sope in 2001. Although its headquarters are in Malakula, the party has fielded candidates in Torba and Tafea Outer Islands electorates. The PPP emphasises the need for urgent agrarian reform and regional development to encourage regional trade and commerce. ${ }^{28}$ It also stresses the need to develop regional centres as hubs for economic activity.

\section{People's Action Party (PAP), established in 2001}

Silas Hakwa, a long-standing VP supporter and former Attorney-General, formed the PAP after his breakaway from the VP in 2001. Its major support base is west Ambae in Penama Province.

\section{Fren Melanesia Pati (FMP), established in 1975}

Formerly known as Charlemagne, Fren Melanesia Pati was formed by Protestant francophone Pisovuke Albert Ravutia in $1975 .{ }^{29}$ Its power base is in the northern islands, particularly in southern Santo Rural constituency, Luganville, Malo/Aore and Malakula. Ravutia was implicated in the rebellion in 1980 and served a term in prison for his involvement. ${ }^{30}$ The party is one of the oldest minor parties and has traded well on its small support base, and the popularity of its founder, winning seats in 1983-87 and 1991-2002.

\section{Grin Pati (GP), established in 2000}

Formed by the Tan Union's Vincent Boulekone, Paul Telukluk and Père Gerard Leymang in July 2000, the Grin Pati's platform was initially to further sustainable development with respect to custom and the environment, regional autonomy for each of Vanuatu's provinces and free enterprise and social welfare especially for elderly people and underprivileged mothers. Currently, MP for Port Vila Urban, Hon. Moana Carcasses, leads the GP.

Although the party claims membership in the global green movement, in practice it provides a parliamentary umbrella organisation for Ambrymese, Malakulan (Namangki Aute) and Tannese (Jon Frum) social movements. While this is not antithetical to its 'green' policies, its environmental credentials have never been challenged.

The GP adheres to a strict delineation between elected members and party officials. Serving MPs cannot hold offices within the party structure. Also included in the GP structure are provisions for chiefs from the Malvatumauri (National Council of Chiefs) to act as political appointees to government departments. 


\section{Jon Frum (JF)}

Until the mid-1990s a constituent of the UMP, the parliamentary wing of Jon Frum constituted part of the Alliance for the Development of Vanuatu (ADV) and is now part of the National Community Association (NCA). In the lead-up to independence, members of the Jon Frum movement instigated an uprising in the southern islands, which was suppressed by the British constabulary. ${ }^{31}$ In practice, JF MPs have been enduring advocates of community development and religious freedom. ${ }^{32}$

\section{Namangki Aute (NA), established in the 1970s}

A breakaway faction of the MANH party, Namangki Aute was formed in the late 1970s by Aimé Maléré and contested Vanuatu's first election in November 1979. Principally a Malakula-based party, NA constitutes part of the Alliance for the Development of Vanuatu (ADV) and is a core group of the GP. Central to its party platform is the development of Malakula as part of a confederation of provinces, a policy that dates to its early resistance to the VP in the 1970s. Included in its policy platform are economic and legislative decentralisation, including the development of urban zones in every province, downsizing the Parliament from 52 to 39 seats (its original number), compulsory voting, recognising the power of chiefs, reinvigorating agricultural cooperatives, alleviating the Value Added Tax's (VAT) effect on the people and recognising and protecting the role of women in society (on the latter issue, the platform does not elaborate further).

\section{Vanuatu Republican Party (VRP), established in 1998}

Former Prime Minister Maxime Carlot Korman formed the Vanuatu Republican Party in preparation for the 1998 elections after his toppling as leader of the UMP. ${ }^{33}$ Although initially involving only Korman and his personal supporters, the party has since extended its influence throughout the northern islands and now attracts strong electoral support in Malampa Province, particularly Ambrym and Malakula. Although Korman is one of Vanuatu's longest-standing and most prominent ni-Vanuatu francophones, other members of the party, such as Donna Brownie from Malekula, are anglophone. Korman has been an enduring advocate of the private ownership of land

\section{Nagriamel (NGM), established about 1967}

Arguably Vanuatu's first political party, the Nagriamel movement emerged on Espiritu Santo in the mid-1960s in retaliation to the widespread alienation of 'dark bush' by French ranchers. Very quickly after its formation, Nagriamel became the vehicle for broad anti-colonial sentiments among local people in the northern New Hebrides and, by the early 1970s, its leadership claimed 10-20,000 adherents spanning from Epi in the central New Hebrides to the Banks and Torres Islands at the archipelago's northerly extension. ${ }^{34}$ From the 1960s until the rebellion in 1980, Nagriamel's platform was antistate, anti-VP and anti-missionary. In the 1970s, the radical liberal ideology of the Phoenix Foundation was incorporated into its ideology. ${ }^{35}$

Nagriamel's influence emanates from Vanafo, north of Luganville, and extends into several northern islands, particularly Pentecost and Ambae, but it is much reduced from its peak in the early 1970s. Ostensibly, the chief's meeting house (nakamal) at Vanafo is 
Nagriamel's supreme deliberative body. Its ideologies remain rooted in the expectation of 'cargo' arriving from America to emancipate the people. Despite its anti-statist ideologies, Nagriamel has regularly fielded candidates in national elections. It last elected an MP its leader, Frankie Stephens - to Parliament in 1995. Stephens is the son of the founder of Nagriamel, the late Jimmy Stephens.

\section{Nevsem Nenparata, established in 2004}

Nevsem Nenparata was first elected to Parliament in 2004, when Thomas Nentu won the Tafea Outer Islands constituency. The party prioritises local development and national unity and represents a local coalition between several of the federalist parties mentioned above. In Erromangan language, nevsem nenparata means 'to come together in peace'. ${ }^{36}$ The party incorporates local supporters of the UMP, VRP, the Greens, MPP and PPP, who have pooled their electoral resources. Much of the impetus to form the party came from local chiefs who sought to end political infighting on Erromango and who were dissatisfied with the existing party system and the lack of interaction between MPs and their constituencies. In particular, the impetus for forming the party came from the fear that the Government would potentially squander Erromomango's natural resources, including sandalwood, if there were no Erromangans in Parliament to protect them. The party also benefited fortuitously from the factional split within the VP in the Tafea Outer Island constituency.

\section{Changing party numbers since 1980}

Constituted by elections held in November 1979, Vanuatu's first Parliament was dominated by the VP, which commanded 26 of the 39 seats (see Table 7.1). Although the VP is often credited with winning 26 seats, it in fact only won 25. Kalmer Vocor was elected on the Natuitanno ticket, but voted with the Government consistently. Natuitanno was eventually subsumed within the VP. Several members of the Modérés elected to Parliament in the November 1979 elections never took their seats. Often considered to have been the trigger for the formal declaration of the Santo and Tanna rebellions, the 1979 elections augured a year of low-level violence, two attempted secessions, the arrest of several MPs, the exile of some of that number and the killing of Jon Frum MP for Tanna, Alexis Yolou. In the aftermath, the VP set about utilising its absolute majority of the House to amend the Constitution and push through whatever legislation it chose.

In the 1983 elections, the VP's majority fell to 24 seats. The VP maintained its dominance of parliamentary proceedings during the second parliament (Table 7.2).

In the 1987 elections, which contested an expanded 46-seat house, the VP won 26 seats (Table 7.3). The UMP, however, consolidated its electoral support, increasing its vote share and consequent representation in the House. ${ }^{37}$ In 1987, Walter Lini suffered a stroke in the US. Increasingly under the influence of the Vietnamese-born businessman, Dinh Van Than, Lini lost favour with his VP comrades - in particular, Secretary-General of the VP, Barak Sope - who sought to marginalize him from the day-to-day operation of the party. Several senior MPs, however, had misgivings about the advisability of Sope leading 
Table 7.1: First Parliament of Vanuatu, 1979-83.

\begin{tabular}{lc}
\hline Party & Seats \\
\hline VP & 25 \\
\hline Pati Federel/UCNH & 5 \\
\hline Independent & 2 \\
\hline Namangki Aute & 2 \\
\hline Natuitanno (VP) & 1 \\
\hline MANH (Mod.) & 1 \\
\hline Nagriamel (Mod.) & 1 \\
\hline Jon Frum & 1 \\
\hline Kapiel & 1 \\
\hline Total & 39 \\
\hline
\end{tabular}

Table 7.2: Second Parliament of Vanuatu, 1983-87.

\begin{tabular}{lc}
\hline Party & Seats \\
\hline VP & 24 \\
\hline UMP & 12 \\
\hline Nagriamel & 1 \\
\hline Namangki Aute & 1 \\
\hline Fren Melanesia Pati & 1 \\
\hline Total & 39 \\
\hline
\end{tabular}

the parliamentary party. The VP was returned to power, but with a reduced majority. By mid-1988, however, these tensions came to a head when the VP Minister of Lands decided to dissolve the Luganville Land Corporation and Vila Urban Land Corporation (VULCAN). The dissolution of the Luganville corporation passed with little protest but in Vila, Barak Sope took the closure of VULCAN to be a reneging on the VP's commitment to customary landowners and an attack on his home community of Ifira (one of the traditional owners of Port Vila land) and on Sope's personal prestige. Sope was eventually demoted from the VP Cabinet. Rather than join the backbenches, he declared his intention to mount a motion of no confidence in Lini, supported by the UMP and four dissident VP members. However, without the support of Sope's faction and with one VP member in the Speaker's chair, the Government had effectively lost control of the Parliament. Sope mounted repeated attacks on Lini as an autocrat and on the VP as a cult of personality.

Trading on his public image as the father of independence, Lini resisted attempts to wrest him of the party leadership and defected to form the NUP in 1991. Donald Kalpokas replaced him as Prime Minister. In the aftermath of the consecutive splits, the VP finally lost power in the 1991 elections. The NUP won 10 seats and formed government with the Korman-led UMP. Barak Sope's MPP absorbed the remainder of the VP's former vote pool and joined the Opposition bloc alongside the remnants of the VP. Throughout the life of the Parliament constituted in 1991, tensions simmered within the governing coalition and within the newly formed NUP.

Several members were uncomfortable with the visible hand of Dinh Van Than in NUP party direction and this erupted in 1993 into a public brawl between party members about Than's authority and Lini's capacity to govern. NUP withdrew from the Coalition Government in 1993. Monopolising on the split, the Korman Government offered ministerial posts to the dissident NUP members, who entered government in 1994 as the People's Democratic Party.

From the outset, the Parliament constituted in the 1995 elections was unstable (see Table 7.4). Although the main parties each claimed that they would be able to constitute 
Table 7.3: Third Parliament of Vanuatu, 1987-91.

\begin{tabular}{lc}
\hline Party & Seats \\
\hline VP & 26 \\
\hline UMP & 19 \\
\hline Independent & 1 \\
\hline Total & 46 \\
\hline
\end{tabular}

Table 7.4: Fourth Parliament of Vanuatu, 1991-95.

\begin{tabular}{lc}
\hline Party & Seats \\
\hline UMP & 19 \\
\hline VP & 12 \\
\hline NUP & 10 \\
\hline MPP & 4 \\
\hline Fren Melanesia Party & 1 \\
\hline Total & 46 \\
\hline
\end{tabular}

Table 7.5: Fifth Parliament of Vanuatu, 1995-98.

\begin{tabular}{lrc}
\hline Party & Seats \\
\hline Unity Front & 13 & \\
$\quad$ VP & 5 & \} 20 \\
$\quad$ Tan Union & 2 & \\
$\quad$ Melanesian Progressive Party & 17 \\
\hline UMP & 9 \\
\hline National United Pati & 2 \\
\hline Independents & 1 \\
\hline Nagriamel & 1 \\
\hline Fren Melanesia Pati & 50 \\
\hline Total &
\end{tabular}

Table 7.6: Sixth Parliament of Vanuatu, 1998-2002.

\begin{tabular}{lc}
\hline Party & Seats \\
\hline VP & 19 \\
\hline National United Party & 13 \\
\hline UMP & 8 \\
\hline Melanesian Progressive Pati & 4 \\
\hline Vanuatu Republican Pati & 2 \\
\hline Fren Melanesia Pati & 2 \\
\hline Grin Pati & 2 \\
\hline Jon Frum & 2 \\
\hline Total & 52 \\
\hline
\end{tabular}

government in their own right, the elections for the extended 50-seat Parliament resulted in no clear majority. The party with the largest number of seats, the Unity Front, did not form government, deferring that right to the next largest bloc, the UMP. The term of Parliament was notable for the split that emerged within the UMP, with both factions claiming to represent the party rank and file. The strength of the feud became clear after the elections when the two UMP factions negotiated separately to form government. One faction attempted to form government with the NUP. The other attempted to form government with the Unity Front. The factional leaders of the UMP vied for the position of Prime Minister. The ramifications were profound. The disintegration of the largest party (UMP) within a Parliament in which no party could claim a majority in its own right meant that even a minor shift in allegiance could — and did — effect a change in government. Between 1995 and 1997, the Government changed three times via votes of no confidence and there were eight major coalition changes. ${ }^{38}$ The period was notable for the inactivity of government ministers: Minister of Finance, Barak Sope, failed to table an Appropriation Bill for 1996-97. In 1996, frustrated by the failure of the 
Government to pay their salaries and allowances, the Vanuatu Mobile Force (VMF) abducted the President to further their claims. In early 1997, government coffers were empty, forcing the Vohor Government to accept the offer of a tied loan from the Asian Development Bank (ADB), which paved the way for the CRP. In January 1998, disgruntled former employees of the VNPF, supported by urban unemployed people, rioted after an Ombudsman's report implicated senior government officials in a preferential loans deal. After three years of endemic political instability, Vanuatu appeared to be on the brink of a serious breakdown of law and order.

Vanuatu underwent its sixth national election in March 1998 (see Table 7.5), in the middle of the parliamentary term. Again, the size of Parliament was extended to 52 seats. Called on the request of Prime Minister Serge Vohor in favour of facing a motion of no confidence from within his own party, the elections resulted in a coalition government between the VP and one of its breakaway factions, the National United Pati (NUP) of Father Walter Lini. Running on a platform of government renewal and accountability, the coalition sought to reverse the political fragmentation of the previous years. It adopted, moreover, the rhetoric of institutional reform. Prime Minister Donald Kalpokas stated:

The people of Vanuatu ... no longer trust the government ... to provide the services that they need ... Investors and workers have lost confidence that it can implement its policies to ensure that the economy grows and in the end raise the standards of living of the people. ${ }^{39}$

While the VP/NUP Government raised hopes of a rapprochement between former comrades, it was undermined eventually by the same problems of previous coalitions governments - internal manoeuvring.

The implementation of the CRP dominated government business. On taking office, it inherited many of the problems of the Vohor Government - particularly, a deficit estimated to be four billion vatu (\$A44 million). Vohor was reported to have provided tax concessions to UMP allies and weak tax-enforcement capabilities. The Kalpokas Government accepted a \$A28.6 million tied loan from the ADB, earmarked for the reduction of the bureaucracy and the implementation of guidelines for public servants. Kalpokas, however, was criticised for the slow pace of reform and the lack of visible indicators of economic growth. Rural constituents were concerned by the introduction of the VAT, which they felt benefited urban dwellers and Chinese (sinois) merchants more than them.

Opposition spokesmen criticised Kalpokas for being beholden to foreign interests (see below) and, facing a motion of no confidence, he resigned, allowing Barak Sope to take power. Despite commanding only four votes in the National Parliament, Sope was able to take office because of a peculiarity of the Standing Orders of the Vanuatu Parliament: rather than being the leader of the majority party, the Prime Minister must be elected by all Members of Parliament. ${ }^{40}$

Between his accession in 1999 and his ouster in April 2001, Sope undertook several perilous financial deals in the hope of pulling Vanuatu quickly from the brink of finan- 
cial disaster, rather than the lengthier and politically unpopular process of institutional reform. The most prominent involved Amerendra Nath Ghosh, who arrived in Port Vila in February 2000 with what was described as 'possibly the world's largest ruby', which he intended to 'donate' to the people of Vanuatu. Ghosh promised to initiate a project to seal the road around Efate, build a walled complex for the Council of Ministers and negotiate with foreign consortia to build a new international airport. ${ }^{41}$ In return for the ruby, it was reported that Ghosh was to receive $\$ A 388$ million in bearer bonds from the Reserve Bank, equal to 140 per cent of Vanuatu's gross domestic product. Had Sope issued the bonds, Vanuatu's total debt would have quadrupled. ${ }^{42}$ His record of financial management was the trigger for a motion of no confidence in March 2001. ${ }^{43}$

Edward Natapei, the leader of the VP, then came to power as leader of a VP/UMP government coalition, committed to following through with its reform agenda. The continued survival of the VP/UMP Government Coalition brought respite from the entrenched political instability of the 1990s, but key obstacles remained, principally poor public opinion of the CRP. By following this course, Natapei signalled his intention to stamp out the form of maverick leadership that Sope embodied, and hopefully to lessen the potential for the economic mismanagement and corruption that Vanuatu had witnessed in the past decade. Natapei's Government included several MPs who had been closely involved with financial scams and had poor records of economic management, but the exigencies of Vanuatu's Parliament meant that he had to ally with one of the larger parties. UMP spokespeople reiterated their allegiance to the VP forcefully and publicly, but key UMP MPs, including the Deputy Prime Minister, had been targeted by the Ombudsman and police for investigation. ${ }^{44}$

Table 7.7: Seventh Parliament of Vanuatu,

\begin{tabular}{lc}
\multicolumn{2}{c}{ 2002-06. } \\
\hline Party & No. \\
\hline UMP & 15 \\
\hline VP & 14 \\
\hline National United Party & 8 \\
\hline Independents & $6^{45}$ \\
\hline Melanesian Progressive Party & 4 \\
\hline Vanuatu Republican Party & 3 \\
\hline Grin Pati & 2 \\
\hline Total & 52 \\
\hline
\end{tabular}

Table 7.8: Eighth Parliament of Vanuatu,

\begin{tabular}{lc}
\multicolumn{2}{c}{ 2004-.$^{47}$} \\
\hline Party & Seats \\
\hline NUP & 10 \\
\hline UMP & 8 \\
\hline VP & 8 \\
\hline Independents & 8 \\
\hline VRP & 4 \\
\hline PPP & 4 \\
\hline Grin Pati & 3 \\
\hline MPP & 3 \\
\hline National Community Association (NCA) & 2 \\
\hline PAP & 1 \\
\hline Namangki Aute & 1 \\
\hline Total & 52 \\
\hline
\end{tabular}


The 2002 elections were fought over the continuance of the ADB-sponsored CRP. ${ }^{46}$ The NUP and MPP campaigned against the program, stating that it was neocolonial and designed to benefit Western powers to the detriment of grassroots ni-Vanuatu. The VP regained power in Vanuatu's seventh Parliament. Despite placing second to the UMP in terms of members elected to Parliament, the VP was able to claim the leadership in government by attracting two independents to join it before constituting the Coalition Government with the UMP. One of that number was Jackleen Reuben Titeck, a VP member disendorsed as a candidate by his local committee, who had won his seat nonetheless.

The VP/UMP Coalition governed until November 2003, when, citing poor attendance at Cabinet meetings and possible collusion with the Opposition, the UMP was dumped. Key UMP MPs were also alleged to have misappropriated funds, although no further action was taken. The UMP was replaced with the NUP, the People's Progressive Party and elements of the ADV, including former Prime Minister Maxime Carlot Korman and Moana Carcasses.

Throughout the term, the Government was criticised for its poor record of local development. Projects were seen to stagnate as the Government prioritised stability and financial accountability, resulting in pressure being exerted on government MPs for more rural development projects. In early 2004, a factional split emerged within the VP, prompted by the leadership aspirations of junior party members. The tension culminated in the temporary split from the party elite of senior members Donald Kalpokas, Sela Molisa, Joe Natuman and Jackleen Reuben Titeck. The term was ended prematurely after the Speaker dissolved Parliament to pave the way for fresh elections. This was prompted by the annulment of the candidacy for President of Alfred Maseng on the grounds that he had a criminal record. Maseng won the Electoral College votes against the Government-favoured candidate, triggering moves towards a motion of no confidence in Prime Minister Natapei, supported by the dissident members of his own government.

Constituted by snap elections called in 2004 after the dissolution of Parliament by the Speaker, the 2004 elections resulted in one of Vanuatu's most fragmented Parliaments. Several senior parliamentarians — including several ministers and former Prime Minister, Donald Kalpokas — were voted from office. In all, 23 sitting members lost their seats. Despite the recognition of the dangers of political instability by the major parties, the 2004 elections demonstrated the progressive Balkanisation of National Parliaments and the possible death of big-issue politics, as voters appeared to favour locally credible social movements, minor parties and independents.

The elections were called to end political instability, but the major parties suffered severe losses. As Table 7.8 demonstrates, parliamentary power is spread relatively evenly between three medium-sized blocs, one with 10 members (NUP) and two with eight members (VP and UMP). Independents or minor parties hold 26 seats in the Parliament: a simple majority. The Parliament will therefore be less stable than any of its predecessors. The Coalition Government formed by Serge Vohor is an unwieldy coalition, incorporating five independents and 23 members of five parties. ${ }^{48}$ Although the Coalition maintains a 28 -seat majority at present, its sustainability is limited by its 
incredible fragmentation. A minor shift in the balance of power could result in the NUP, the UMP or several smaller parties being dispensed with in favour of the VP.

A (more-or-less) stable Cabinet was formed in August 2004, referred to misleadingly as a 'government of national unity'. Despite threats from the Prime Minister, Serge Vohor, that he would call a 'state of emergency', negotiations remained peaceful. Much of the impetus for instability in the preceding few months had come from the elections for President. In August, that position was filled by one of the frontrunners in the earlier collegial run-offs, Kalkot Matas Kelekele, a member of the original independence movement and a former VP and NUP stalwart.

Earlier that month, NUP had joined UMP in government, giving it two major blocs of eight members each, and commensurate shares of Cabinet portfolios. The remainder were divided between the minor members of the Coalition. Included in the Cabinet was breakaway VP member for Tanna, Joe Natuman, a Vanua K MP, who holds the Ministry of Education portfolio. ${ }^{49}$ Former Prime Minister Barak Sope was granted the Ministry of Foreign Affairs, possibly signalling a volte-face in Vanuatu's diplomatic relations with the regional powers, Australia and New Zealand. Accepting large soft loans from the People's Republic of China, the Vohor Government has become comfortable resisting Australian policy imperatives, the good governance agenda and core programs undertaken under the CRP, including strengthening Vanuatu's legal frameworks. Indeed, almost immediately after taking power, Vohor's Cabinet mounted attacks on the high number of foreign advisors in Vanuatu - prompting rebukes from the opposition VP and criticised Australia as racist for its resistance to Melanesian labourers working in Australia. ${ }^{50}$ In the past few years, gaining access to the Australian labour market has become popular political rhetoric. In early September 2004, the Government terminated the appointments of two senior AusAID consultant lawyers working in the State Law Office (Attorney-General's Department) and expelled Australian Federal Police liaison officers, although it later rescinded both decisions.

\section{The SNTV electoral system}

Vanuatu's legislature consists of a unicameral Parliament containing 52 seats, ${ }^{51}$ elected every four years, using a single non-transferable vote (SNTV) electoral system. ${ }^{52}$ Members of Parliament are elected on the basis of universal suffrage through an electoral system that includes multi-member, SNTV constituencies to 'ensure fair representation of different political groups and opinions. ${ }^{53}$

Constituencies vary in size depending on their social make-up, although there are significant discrepancies between the number of people represented and the number of seats in each constituency. At the time of the 2002 elections, constituencies varied in size from seven-member to single-member constituencies. Generally speaking, representation is geared in favour of rural constituencies. The largest constituency, Port Vila (with 18,978 registered voters) elects six members to Parliament. The three seven-member constituencies are Tanna (17,212 registered voters), Malakula $(15,789)$ and Santo Rural $(14,411)$. Rural Efate $(15,556)$ elects only four members to Parliament despite being larger than Santo Rural and only marginally smaller than Malakula. In comparison, 
Pentecost also elects four members to Parliament, despite having only 9,440 registered voters. The smallest constituency is the Shepherds Group of Islands, with 940 registered voters, who elect one member (see Figure 7.1).

The Anglo-French Condominium introduced the SNTV electoral system in preparation for the 1975 elections for the National Representative Assembly (NRA), the precursor to Vanuatu's National Parliament. It allowed the colonial powers to avoid the involved and politically contentious process of setting up electoral wards and it kept the electoral system as straightforward as possible, which was considered crucial to allow for democracy to operate in a society with apparently limited literacy levels. ${ }^{54}$ Arguably, the system was also devised with the intention of dispersing the absolute electoral dominance of the VP in the lead-up to independence, ensuring some level of representation for the VP's diverse, but minority opposition and hopefully lessening the impetus for rebellion, which was prevalent in the $1970 s .{ }^{55}$ It failed on both counts. The VP won the 1979 elections resoundingly, claiming an absolute majority in the National Parliament. Sparked by their losses in the election, sections of the Modérés attempted secession.

In practice, the element of proportional representation contained in the SNTV system cemented the dominance of the majority parties (the VP and UMP) for the first decade after independence while simultaneously allowing representation for smaller parties, especially in larger multi-member constituencies. According to the Vanuatu Electoral Commission, SNTV limits the incentive for party fragmentation contained in other proportional representation systems. ${ }^{56}$ The benefits under the system for large parties with concentrated voter support are that they are able to receive a substantial seat bonus, such as the VP received between 1979 and 1987. ${ }^{57}$ Nonetheless, since the late 1980s, the majority parties have splintered and there has been an upsurge in the number of independent candidates running for — and winning — office.

The system has inbuilt restrictions on overstocking electorates with candidates from the one party. In multi-member constituencies, SNTV requires party organisers to educate their electors to avoid popular candidates attracting overwhelming majorities, while their less popular stablemates are unsuccessful, as occurred in the Malakula constituency in 2002. Four UMP candidates attracted a total of 1,078 votes in the Malakula electorate but none was elected, whereas Namangki Aute - the Malakulan social movement - ran two candidates, who polled 978 votes collectively; both won seats in the National Parliament. Enacting strategies to avoid such vote-splitting has become a major preoccupation of Vanuatu's political planners.

According to Howard van Trease, a major benefit of the system is that it 'allows minority cultures to be represented in the most culturally diverse country - with 100 languages for 200,000 people - in the world'. ${ }^{58}$ A consequence of this aspect of SNTV is that levels of representation, quantified in terms of numbers of successful votes cast, are decreasing. ${ }^{59}$ In turn, this allows members to be elected with minority shares of the vote. For example, in 1998, UMP's Henri Taga, one of the six MPs elected from the Port Vila constituency, polled just 352 votes out of the nine thousand or so votes cast. ${ }^{60}$

Once the dominance of the major parties was broken in the 1990s, the propensity of the SNTV system to reward smaller parties became obvious. Small parties with concen- 
trated localised voter bases stand to beat large parties with dispersed voter bases, allowing Vanuatu's provincial social movements such as the Jon Frum movement significant advantages within the confines of its Tanna electorate given its large support base and limited pool of eligible candidates. Small, locally credible parties that can mobilise concentrated support have an excellent chance of electoral victory. Thus, while the VP, NUP and UMP are able to command votes on a national scale, the increasing number of candidates contesting each seat means that electoral results are increasingly difficult to predict and the smallest of shifts in voter support can effect major changes in the number of members elected to Parliament and the success or failure of the more established political parties.

Bearing in mind these aspects of the SNTV system, the major parties have tailored their electoral strategies accordingly, monitoring closely the number of candidates preselected by their respective national committees in preparation for elections to avoid overstocking electorates. Nonetheless, no strategies have been able to counter the tendency for national elections to result in a high turnover of candidates. In the 2004 national elections, for example, 23 of the 52 Members of Parliament were not returned. The VP, beset by internal struggles, lost six seats, not taking into account the eventual political allegiances of the dissident Vanua K MPs.

The major victors were the smaller regionally based parties. The system has allowed for the proliferation of candidates, which propels political instability and is exacerbated by it. As I argue below, given the high incidence of factional splits in Vanuatu, the predisposition of the system to reward small groups makes unwieldy coalitions a necessity for forming government.

At present, little political will is directed towards reforming the electoral system. The major parties, however, recognise that the system allows for the election of minor parties relatively easily. Given the increasing swings against the major parties, it is likely that some measures will be taken to secure governments in office, such as the organic law reforms undertaken in PNG, or an alteration in the ways in which the Executive is constituted; that is, reform to the SNTV electoral system.

\section{Growing disenchantment}

Another feature of Vanuatu's electoral politics is the increasing disenchantment with the system by local people. Since independence in 1980, voter turnout has declined steadily. In $1979,90.32$ per cent of eligible voters went to the polls. ${ }^{61}$ In 1991, this number had dropped to 71.3 per cent. ${ }^{62}$ In the 2002 elections, the overall turnout had stabilised at 63 per cent, although by-elections have attracted much lower turnouts: in the February 2001 by-election in Malekula, voter turnout was just 40 per cent of registered voters. ${ }^{63}$

These trends suggest widespread disenchantment with the electoral system. Although civic education programs have targeted rural communities explicitly to educate voters on the roles of Members of Parliament and public servants, ${ }^{64}$ significant confusion about the role of parliamentarians exists in both rural and urban areas. Officers of the Vanuatu Electoral Commission and its support organisations are abused routinely in rural areas because they are confused with party campaigners. No continuing voter education programs have been implemented and neither the Electoral Commission nor the Parliament have the resources to support them. 
Key local leaders have argued that democratic government is leading Melanesian people inexorably to calamity. The apparent creation of divisions through politics voiced in Bislama as politik — is seen by many ni-Vanuatu to augur the societal violence witnessed in the Solomon Islands or PNG. A former member of the National Parliament in Vanuatu and now a regional non-governmental organisation director, Hilda Lini, attempted to capitalise on this belief when she called for the endorsement of a new, more thoroughly indigenous form of governance in Vanuatu: 'This outdated Western system of democracy will continue to corrupt Melanesia, resulting in the continuous uncontrolled crime, violence and poverty [and] ongoing crisis. ${ }^{65}$ An enduring irony of Vanuatu politics is that while public criticisms of the fragmented National Parliament and the apparent inertia of governments are commonplace, voters have discarded the major parties in favour of locally credible independent candidates or members of smaller parties. And it is the increasing presence of independents and smaller parties that motors political instability.

It is to the effects of the progressive disintegration of Vanuatu's political parties in the past eight national elections that we now turn.

\section{The implications of political fragmentation}

Historically, the major precipitants of party fragmentation have been leadership challenges within the major parties, prompted by the highly personalised nature of Vanuatu politics, in which MPs vie for factional and, ultimately, party dominance as a matter of routine. The losers of such contests often form their own parties, attracting factional supporters to their new banners and temporarily reducing the influence of the original party. Such dynamics precipitated the factional splits within the VP in 1988 and 1991 and are a continuing irritant to party leaders. The VP's increasing problems of membership fidelity are impelled by the aspirations of younger politicians whose patience for the party's old guard - many of whom were architects of the independence movement - has waned. Among these elder statesmen, there is the perception that the younger aspirant MPs lack the ideological coherence of Vanuatu's first generation of political leaders. The thwarted ambitions of individual politicians seeking advancement within party structures have provided the impetus for party splits.

Political fragmentation is also often motivated at the grassroots level. Dissatisfaction with the performance of political parties or the fear that politicians are subverting a community's interests to opportunistic ends motivates community leaders to break away from larger political parties. Local community leaders (such as chiefs and pastors) play a crucial role in the initial selection and endorsement of candidates and they continue to exert influence throughout the incumbency of a member. This relationship is less pronounced in senior politicians, but few are entrenched enough to completely ignore their constituency lest their support be removed. The significant grassroots contribution to these processes makes remedying the situation more difficult. Given that grassroots niVanuatu consider the establishment of new political parties to be a marker of leadership skills, there are few visible institutional or social disincentives for politicians to maintain party coherence rather than breakaway or stand as independents. This situation has 
created several parties whose platforms are very similar but whose leaders routinely appear to be opposed, such as the VP, the MPP and NUP.

\section{Coalitions}

Coalitions have been a regular, albeit transitory, feature of Vanuatu politics since the formation of the Modérés grouping — the precursor to the UMP — in the mid-1970s. After the fragmentation of the VP, coalitions became necessary vehicles for the formation of government. Indeed, each government since the 1991 elections has been a coalition. Such coalitions, however, have often proved precarious, being plagued by fierce infighting and competition over ministerial posts. Coalition member parties engage in frenetic efforts to progress upwardly within governments, mostly with the intention of claiming the prized post of Prime Minister or one of the other preferred portfolios. A particular responsibility of the Prime Minister since the late 1990s has been to mediate these tensions; to ensure his position and the position of his party at the apex of the State - and thereby ensure access to the resources and networks of distribution for their constituents - with workable and more-or-less stable coalitions. These tensions must be mediated through inducements (ministerial portfolios, the appointment of political adherents and wantoks to party and bureaucratic positions) and sanctions (censure, expulsion), the latter an absolute last resort because of its tendency to result in further fragmentation. Largely, opposition members are denied access to government resources, motoring their often-frantic attempts to rejoin the Government ranks. Fragile coalition governments are often forced to 'horse-trade' to maintain their hold on power and opposition parties readily accept ministerial posts, parliamentary committee positions or parliamentary offices (such as Speaker) as inducements. Indeed, one of the major tasks of opposition parties is to find their way into government, however they choose.

Increasingly, opposition parties have also formed coalitions to present unified fronts to incumbent administrations, although they have generally been short-lived. The first major opposition coalition to be formed post-independence was the Unity Front incorporating the VP, Melanesian Progressive Party, Tan Union and Nagriamel - created in 1995. 66 The Unity Front was formally disbanded in mid-August 1996, when a new grouping known as MTF, ${ }^{67}$ combining the Melanesian Progressive Party, Vincent Bulekone's Tan Union and the Fren Melanesia Pati of Albert Ravutia, emerged and joined forces with a UMP faction and the NUP to topple the Korman Government. Some coalitions are incredibly short-lived: the Opposition Tokemau Federation, comprising the UMP, NUP, VRP and the MPP, existed only from April to May 2002.

These tendencies necessarily propel political centrifugalism within the parliamentary parties and, therefore, within the National Parliament. A situation has arisen in which opposition and government coalitions are intrinsically frail. Failure to provide desirable positions to coalition members can result in loss of government. Even the slightest shift in power in Parliament can initiate a complete reorganisation of ruling coalitions, such as occurred between 1995 and 1997, and present almost insurmountable obstacles to policy-making and implementation. ${ }^{68}$ 


\section{The reform agenda}

The major casualties of national political manoeuvring during the 1990s were parliamentary oversight, law-making and durable policy formation and implementation, especially with relation to macro-economic policy. ${ }^{69}$ In periods of intense political instability, policy formulation, even at its most fundamental level, was subordinated to horsetrading. For example, between his inauguration as Minister of Finance in February 1996 and his eventual dismissal from Cabinet in mid-1997, Barak Sope had failed to provide a development budget or an annual budget for the previous two years. ${ }^{70}$ More recently, it has become apparent that the regular incapacitation of parliamentary sessions in the 1990 s contributed to the dominance of the Legislature by an unaccountable Executive. ${ }^{71}$ With public scrutiny diverted by a succession of political dramas, several short-lived governments stripped state coffers and sold off state assets, often to themselves as private citizens. $^{72}$ During the mid-1990s, corruption became a primary means of advancement for government MPs, particularly those who sought to augment their own wealth with resources misappropriated from the State.

In early 1997, Vanuatu was virtually bankrupted and Serge Vohor — then UMP Prime Minister — began the implementation of the CRP, supported by the ADB and other foreign aid donors, citing the need for government renewal and the overhaul of Vanuatu's social, political and economic structures. According to its authors, the CRP was the blueprint by which the 'poor performance of the institutions of government' would be rectified through the strengthening of the Office of the Ombudsman and the enactment of a leadership code. ${ }^{73}$

The impact of the CRP on party policies has been indirect but nonetheless significant. Fuelled by reports of the negative impact of structural adjustment programs in PNG and the widespread pessimism about Westminster democracy in Vanuatu mentioned above, the fear that the CRP might endanger the sovereignty of ni-Vanuatu has been an enduring theme in political rhetoric since 1997. Increasingly, support or otherwise for the CRP has been a point of differentiation between the parties. Barak Sope, the leader of the MPP, has stated that the CRP would cause suffering to the people of Vanuatu and 'serves the interests of Australia and New Zealand', although in office he has been forced to grant the project tacit support. ${ }^{74}$ Conversely, the VP has supported the program openly.

Reforms enacted under the CRP have encouraged some level of political stability by drawing attention to the weak state of Vanuatu's economy and the potentially disastrous effects of unaccountable governance. Furthermore, the ADB has started an institutional strengthening project in the National Parliament to improve the support mechanisms available to MPs and thereby foster improved national leadership.

\section{Gender}

Another casualty of political instability has been the inclusion of women in public decision-making. ${ }^{75}$ Despite the involvement of several women in the early nationalist movements and continuing programs supported by the UN to support women's election to public office, only four women have ever been elected to Vanuatu's National 
Parliament. ${ }^{76}$ In addition to their poor representation in the National Parliament, women represent only 9 per cent of the 300 or so decision-making positions in the country's 30 key government and private institutions, a situation that worsened during the political instability of the 1990s when women were actively marginalised from decision-making bodies. ${ }^{77}$ These statistics reflect broader issues of gender imbalance in Vanuatu, where women's roles in the public sphere are limited by significant cultural and institutional constraints. ${ }^{78}$ Women's right to participate in decision-making positions has often been challenged by conservative institutions such as the Malvatumauri. In an environment where references to kastom - practices believed by local people to be indigenous - are prevalent in public life, women's empowerment is often cast on the side of Western, and therefore divisive, influences.

The UN Fund for Women (UNIFEM) supported the creation of the Vanuatu Women in Politics (VANWIP) Project in 1995 to encourage women to run for public office. In the 1995 and 1998 elections, the major parties were forced to deploy women members to actively campaign against VANWIP candidates in their electorates. While VANWIP was unsuccessful, each of the major parties consequently incorporated some level of gender recognition into their respective platforms, recognising potential pay-offs in the form of electoral support. The effects of this platform shift were limited. Only the VP incorporated detailed strategies for women's empowerment in its party platform in a detailed manner, although most parties now have women representatives on their executives or support their election in principle. One effect of women's poor representation in Parliament is the relative ease with which male MPs derail legislation, such as the Family Protection Bill (proposed anti-domestic violence legislation). The Family Protection Bill was cleared by the VP/NUP Cabinet for tabling in Parliament in 1999 and again by the VP/NUP Government in 2004, but was delayed by political instability or withdrawn by less-sympathetic regimes such as Barak Sope's Coalition (1999-2001). However, the UMP led Government of Serge Vohor briefly championed the bill, recognising that the VP failed to get it past the council of ministers. Vohor's Government fell in 2004. The Malvatumauri remains opposed to the involvement of women in public decisionmaking, meaning that often, while paying lip service to gender empowerment, political parties opt to incorporate chiefly representatives into their platforms - almost a mandatory strategy to legitimate electoral support — and marginalise women further.

Given the efforts of UNIFEM and VANWIP mentioned above, it is ironic that the two current serving women MPs - Isabelle Donald (VP) and Leinavao Tasso (independent), both from Epi - won their seats on their longstanding commitment to voluntary community service through local church organisations, rather than through the networks of the VNCW, a major stakeholder in VANWIP. VNCW officials are often considered by local women's groups to be overpaid and inefficient, beset by the same internal squabbling as the major political parties.

While they have had little success in winning election, from a gender perspective, the preparedness of women to run for office is heartening. Whether they are more or less susceptible to the centrifugal forces that their male counterparts are subjected to in office remains to be seen. 


\section{Conclusions and projections}

Given the fragmentation of the VP and the further erosion of the major parties' electoral support in the snap election of 2004, it is likely that Vanuatu will undergo further political instability in the coming parliamentary term. In an environment of such instability, the formulation of policy will be subjected to further strains as the political manoeuvring in Parliament is intensified by the reliance on numerous parties to form government, a situation only intensified by the turn against the major parties.

Should local stakeholders seek to arrest these developments, reform to the electoral system will be necessary; removing the tendency of the SNTV system to reward smaller local parties will remove one of the impetuses for political fragmentation. Already, local strategies to combat political instability, based on local leadership, are increasingly visible. The formation of the Nevsem Nenparata alliance offers a case in point. At the movement's foundation, its organiser, Chief Mike Yori, stated:

before Independence, the chiefs held power and everything worked correctly. Immediately after Independence it was the VP which rules [sic]. Then the government split and everything deteriorated. Unity doesn't any longer seem possible with politics. Now we must go back to the chiefs and enable them to sort out how we can again find the pathway to unity. ${ }^{79}$

Indeed, inspired by widespread disillusionment with the Westminster-style system of government, such sentiments will only rise with further political instability. Local strategies such as Nevsem Nenparata, however, are unlikely to stabilise the National Parliament. Given the geographic, ethnic and cultural diversity of Vanuatu, an increasing emphasis on local networks and local knowledge will in all likelihood create an equally diverse Parliament with no unifying ideologies, the implausibility of Vanuatu's major political parties disappearing overnight notwithstanding.

Vanuatu's political culture offers some of the greatest obstacles to political stability. Electoral results since 1980 demonstrate the subordination of national concerns to local ones in Vanuatu politics and imply the shift from issues of national significance driving politics (decolonisation, non-alignment) to issues of more local importance (local development, responsive local representation, access to development funds), exemplified by the increasing support for locally credible - perhaps parochial - candidates whose major platforms are local development above all else. No MP can afford to ignore entirely local demands in favour of the abstract principles of national development and good governance. Unfulfilled promises to constituencies carry with them the threat of electoral defeat for any MP. Nonetheless, little consideration is given in regional communities to the relationship between national political instability and support for local independent candidates or those from minor parties. Arguably, it is the focus on local concerns that propels political instability, as the power of the established political parties is eroded by increasing numbers of independents and minor parties in the National Parliament. It is not simply that the SNTV system erodes the support bases of the established parties. Their electoral attrition implies also their failure to satisfy local demands for reciprocity; 
local independents and minor local parties are seen to be less prone to the dictates of centralised party executives and are plausibly more responsive to local demands. There are several paradoxes contained within Vanuatu's contemporary political culture. Larger parties, less receptive to specific local demands, are nonetheless more likely to foster a greater degree of political stability in the National Parliament simply because they can sidestep the politically risky issue of maintaining a simple majority in Parliament by allying themselves with a handful of independents and minor parties, whose allegiance goes to the highest bidder. At present, however, electoral returns appear to favour smaller parties and independents, and their presence in the Parliament will be a continuing source of political instability. Vanuatu can ill afford to be subjected to renewed political instability such as it experienced during the 1990s.

\section{Footnotes}

1 I thank Roland Rich, Eric Wittersheim, Bob Makin and Gordon Haines for their comments on drafts of this chapter. All mistakes are my own.

2 See Ambrose, David. 1996. 'A Coup That Failed? Recent Political Events in Vanuatu.' Discussion Paper 96/03. State, Society and Governance in Melanesia Project (SSGM). p. 1.

3 National Statistics Office, Vanuatu. 1999. The 1999 Vanuatu National Population and Housing Census. Port Vila: National Statistics Office. p. 15.

4 MacClancy, Jeremy. 1980. To Kill a Bird with Two Stones. Port Vila: Vanuatu Cultural Centre; MacClancy, Jeremy. 1981. 'Current Developments in the Pacific: From New Hebrides to Vanuatu, 1979-80.' Journal of Pacific History, Vol. 16, No. 2. pp. 92-104; van Trease, Howard. 1987. The Politics of Land in Vanuatu: From Colony to Independence. Suva: University of the South Pacific (USP).

5 Miles, William F. 1994. 'Francophonie in Post-Colonial Vanuatu.' Journal of Pacific History, Vol. 29, No. 1; Forster, R. A. S. 1980. 'Vanuatu: The End of an Episode of Schizophrenic Colonialism.' Round Table, 280.

6 Miles, William. F. 1994, op. cit. pp. 49-50; see also Miles, William. 1998. Bridging Mental Boundaries in a Postcolonial Microcosm: Identity and Development in Vanuatu. Honolulu: University of Hawai' $\mathrm{i}$ Press; Molisa, Grace, Nikenike Vurobaravu and Howard van Trease. 1982. 'Vanuatu — Overcoming Pandemonium.' In Politics in Melanesia, Suva: Institute of Pacific Studies (ISP), USP. pp. 83-115; van Trease, Howard (ed.) 1995. Melanesian Politics: Stael Bong Vanuatu. Suva: ISP-USP.

7 Morgan, Michael G. 2003. 'Politik Is Poison: The Politics of Memory Among the Churches of Christ in Northern Vanuatu.' PhD, The Australian National University (ANU). pp. 206-21.

8 Tatangis, Amos. 1995. 'Efate.' In Howard van Trease (ed.), op. cit. pp. 352-3.

9 See e.g., transcript of Jimmy Stephens' trial, cited in Voice of Vanuatu, November 27, 1980; Beasant, John. 1984. The Santo Rebellion, an Imperial Reckoning. Honolulu: University of Hawai'i Press. pp. 142-3; MacClancy, Jeremy, 1981 and 1980 op. cit.; Shears, Richard. 1980. The Coconut War: Crisis on Espiritu Santo. Melbourne: Cassell; Miles, William F., 1998, op. cit.; Molisa, Grace et al. op. cit.

10 See e.g., Virelala, Jean Paul. 1995. 'To be Francophone in Vanuatu.' In Howard van Trease (ed.) op. cit.

11 Ghai, Yash. 1988. Law, Government and Politics in the Pacific Island States. Suva: ISP-USP. p. 16.

12 Plant, Chris (ed.) 1977. New Hebrides, the Road to Independence. Suva: ISP-USP and South Pacific Social Sciences Association. pp. 25-6.

13 MacClancy, Jeremy, 1981 and 1980, op. cit.

14 Beasant, John. op. cit. 
15 McQueen, Norman. 1988. 'Beyond Tok Win: The Papua New Guinea Intervention in Vanuatu, 1980.' Pacific Affairs, Vol. 61, No. 2; Morgan, Michael G., 2003. op. cit.; Rodman, William. 2000. 'Outlaw Memories: Biography and the Construction of Meaning in Postcolonial Vanuatu.' In Pamela J. Stewart and Andrew Strathern (eds), Identity Work: Constructing Pacific Lives.

16 Beasant, John. op. cit.; Leder, Jean. 1981. Les Cent Jours Du Bout Du Monde: Autopsie D’une Tragedie. Noumea.

17 Otto, Ton. 1997. 'After the "Tidal Wave": Bernard Narakobi and the Creation of the Melanesian Way.' In Ton Otto and Nicholas Thomas (eds), Narratives of Nation in the South Pacific, Studies in Anthropology and History, Amsterdam: Harwood Academic Publishers. Cf. Nkrumah, Kwame. 1963. Africa Must Unite London: Heinemann; Otto, Ton. 1991. 'The Politics of Tradition in Baluan Social Change and The Construction of the Past in a Manus Society.' PhD, ANU; Owusu, Maxwell. 1979. 'Evolution in the Revolution: Nkrumah, Ghana and African Socialism.' Africa Today, Vol. 26, No. 2. Albinski, Henry. 1995. 'The Security Perspective.' In Fyodor Mediansky (ed.), Strategic Cooperation and Competition in the Pacific Islands, Sydney: Centre for South Pacific Studies, University of New South Wales and Australia-New Zealand Studies Center, Penn. State. p. 128.

19 VP. 2002. 'Vanua'aku Pati Platfom.' Port Vila.

20 Trading Post, April 25, 2002. p. 3.

21 Trading Post, August 25, 2001.

22 Boulekone, Vincent. 1995. 'The Politics of Tan Union.' In Howard van Trease (ed.), op. cit. p. 203.

23 National United Party (NUP). Constitution. Section 4(a).

24 Vanuatu Weekly, June 14, 1997.

25 Boulekone, Vincent. op. cit. pp. 199-201.

26 Port Vila Presse, April 6, 2002. p. 3.

27 Morgan, Michael G. 1998. 'Political Chronicles 1995-1998.' Journal of Pacific History, Vol. 33, No. 3.

28 Trading Post August 18, 2001. p.1

29 Plant, Chris. op. cit. pp. 10, 50.

30 Radio Vanuatu News Bulletin, December 7, 1982.

31 Calvert, Ken C. 1980. 'Martyrs and Mercenaries.' Pacific Islands Monthly. p. 31.

32 E.g. Trading Post, November 24, 2001. p. 2.

33 Morgan, Michael G. 1998. op cit."

34 Jackson, A. L. 1972. 'Current Developments in the Pacific: Towards Political Awareness in the New Hebrides.' Journal of Pacific History, Vol. 7. p. 177; cf. Plant, Chris. op. cit.

35 Doorn, Robert. 1979. A Blueprint for a New Nation: The Structure of the Nagriamel Federation. New York: Exposition Press; Stephens, Jimmy, in Plant, Chris, op. cit. p. 40.

36 Port Presse Online, May 28, 2004.

37 Howard van Trease (ed.), op. cit. pp. 73-118.

38 Morgan, Michael G, 1998. op. cit.

39 Trading Post, February 18, 1998. p. 4.

40 Standing Orders of Parliament/Reglement Interieur Du Parlement, (January 1, 1982), s.8 (1-4).

41 Nasara, April 14, 2001.

42 Australian Financial Review, February 26, 2001.

43 Morgan, Michael G. 2003. 'Converging on the Arc of Instability? The Fall of Barak Sope and the Spectre of a Coup in Vanuatu.' In R. J. May (ed.), Arc of Instability? Melanesia in the Early 2000s, Canberra and Christchurch: SSGM, ANU and the Macmillan Brown Centre for Pacific Studies.

44 Trading Post, May 19, 2001.

45 Of these, two were affiliated closely with the VP.

46 See Port Vila Presse, April 20, 2002. p. 1.

47 CPOD, Election Tracker Overview [web site] (Centre for Public Opinion and Democracy, ca2004 [cited September 7, 2004]); available from http://www.cpod.ubc.ca/admin/collateral/pdfs/tracker/Vanuatu_2002_Parl.pdf.

48 Vanuatu Daily Post, July 9, 2004. p. 2.

49 The Independent, August 7, 2004. p. 2. Fellow Vanua K supporter, Sela Molisa, remained a member of the opposition VP backbench. Former Foreign Minister Moana Carcasses became the Minister of 
Finance. Tannese UMP MP Judah Isaac became the Minister of Health. The Vanuatu Republican Party's Pipite Marcellino took responsibility for the Minister of the Comprehensive Reform Program. Pierre Tore, VRP Port Vila, became the Minister for Youth and Sports.

50 Vanuatu Daily Post, August 11, 2004. p. 2. Vohor stated: 'If ni-Vanuatu were white skinned like the Samoans or the Cook Islanders, perhaps the Australians would not be reluctant in relaxing the immigration laws to accommodate unskilled labourers to Australia.'

51 Since 1980, the number of seats in Parliament has been raised from 39 to 52.

52 Representation of the People Act [Cap 146], No. 1 of 1987 (June 28, 1982). Republic of Vanuatu. Constitution. (1980), s.17.

53 Vanuatu. Constitution. s.17-19.

54 Howard van Trease (ed.) op. cit. p. 145.

55 Vanuatu Electoral Commission. 2002. 6th General Elections Report. Port Vila: Vanuatu Electoral Commission. p. 8; Howard van Trease (ed.), op. cit.

56 Vanuatu Electoral Commission, op. cit. pp. 7-9.

57 Ibid. p. 8.

58 The Independent, July 24, 2004. p. 2.

59 van Trease, Howard. 2004. 'Vanuatu’s National Elections, July 2004: Continuity and Change.' In SSGM Seminar Series, Canberra: State, Society and Governance in Melanesia Project.

60 Vanuatu Electoral Commission, op. cit. Fig. 15; Port Vila Presse, April 6, 2002. p. 3.

61 Nabanga, November 21, 1979. pp. 4-5.

62 CDP, Vanuatu Election Results, 1991 [web site] (Centre for Democratic Performance, March 6, 2002, ca2004 [cited May 2004]).

63 Vanuatu Electoral Commission, op. cit. p. 32.

64 Bolenga, Jeanette. 1998. A Report on Wan Smol Bag Theatre's Voting Rights Play During the 1998 General Elections in Vanuatu. Port Vila: Vanuatu Electoral Office.

65 Port Vila Presse, October 27, 2001. p. 1.

66 Pacnews, November 15, 1994.

67 The coalition took its name from the first initials of its constituent parties: (M)elanesian Progressive Party, (T)an Union and (F)ren Melanesia Pati.

68 Morgan, Michael G. 1998. op. cit. p. 287.

69 ADB. Annual Report 1997. Singapore: Asian Development Bank, 1998; ADB, 2003, Priorities of the People: Hardship in Vanuatu. Manila: Asian Development Bank; ADB. 2001. Vanuatu 2001 Economic Report: Strengthening Development Policies.

70 Vanuatu Weekly, August 10, 1996. p. 2.

71 UNDP. 2001. Integrating Reform: Legislative Needs Assessment, Republic of Vanuatu. Suva: UNDPGOLD. Cited online at http://www.undp.org.fj/gold/docs/vanuatul.pdf

72 Vanuatu Office of the Ombudsman. 1995. First Annual Report to Parliament by the Ombudsman of the Republic of Vanuatu.

73 Vanuatu. 1997. Comprehensive Reform Programme, Draft Endorsed by the National Level Task Team for Presentation to the Council of Ministers and National Summit. Port Vila: Office of the Prime Minister. p. 4.

74 Trading Post, May 19, 2001; Trading Post September 17, 1997.

75 Molisa, Grace Mera. 2001. The Vanuatu Governance and Accountability Project Output 1.2 Van/97/001 Vanwip Component Project Completion General Report. Port Vila: Vanuatu National Council of Women; Molisa, Grace Mera. 2002. Women and Good Governance. Port Vila: Blackstone Publishing.

76 Maria Crowby was elected UMP MP for Port Vila in 1987. Hilda Lini was elected as a VP MP for Port Vila in 1987 and then served as NUP MP, 1991-98. Isabelle Donald was elected VP MP for Epi for 2002-04, and 2004-. An Epi independent, Leinavao Tasso, was elected to parliament in 2004.

77 Molisa, Grace Mera, 2002. op. cit.

78 See e.g., McLeod, Abby. 2004. Women, Peace and Security: An Examination of the Role of Women in the Prevention and Resolution of Conflict in Vanuatu. Suva: UNIFEM.

79 Port Vila Presse Online. May 28, 2004. 